\title{
Analisis Pengaruh Distori Harmonisa Pada Pemasangan Grid TIE Inverter Dengan Menggunakan Simulink MATLAB
}

\author{
I Dewa Gede Bayu Satya Nugraha ${ }^{1}$, Cok Gede Indra Partha ${ }^{2}$, I Wayan Arta Wijaya ${ }^{3}$
}

\begin{abstract}
On power system network, there are several issues greatly affect the power quality of power system, one of which is harmonic. Harmonic is symptom formation of sine waves with frequencies multiple of fundamental frequency. Harmonic wave rides on a pure sine wave, wich form defect wave that is the sum of a pure sine wave with harmonic wave. Harmonic occurs due to the nonlinear load generated by the electric device, for example is inverter. In inverter harmonic occurs, due to switching process. This project calculated distortion harmonic wave generated in inverter before and after it is mounted filter. Type of filter used here is passive filter (single-tunned filter). The simulation result by using simulink MATLAB software, show that the THDv values are $38.94 \%$ and $27.43 \%$ for the initial condition and filter-used condition respectively. As the THDv value in the filter-used condition is out of IEEE standard, it is required to install some more filters.
\end{abstract}

\begin{abstract}
Intisari-Dalam jaringan tenaga listrik, terdapat beberapa permasalahan kualitas daya yang sangat mempengaruhi suatu sistem tenaga listrik, salah satu adalah harmonisa. Harmonisa adalah gejala pembentukan gelombanggelombang sinus dengan frekuensi kelipatan dari frekuensi fundamental. Gelombang harmonisa akan menumpang pada gelombang sinus murni, sehingga akan terbentuk cacat gelombang yang merupakan hasil penjumlahan gelombang sinus murni dengan gelombang harmonisa. Harmonisa terjadi akibat adanya beban nonlinier yang dihasilkan oleh peralatan listrik, salah satu contohnya adalah inverter. Pada inverter, harmonisa terjadi akibat adanya proses switching yang terjadi ketika inverter mengubah arus DC menjadi arus AC. Pada Penelitian ini akan dihitung berapa distorsi harmonisa yang di hasilkan pada inverter sebelum terpasangnya filter dan sesudah terpasangnya filter, dengan menggunakan software Simulink MATLAB. Pada penelitian ini menggunakan filter pasif berupa single-tuned filter, hasil simulasi yang telah dilakukan pada kondisi sebelum terpasangnya filter untuk nilai THDv sebesar $38.94 \%$ dan sesudah terpasangnya filter sebesar $27.43 \%$. Selisih nilai, sebelum terpasang filter dan sesudah terpasangnya filter adalah sebesar $11.51 \%$. hal ini masih melebihi standar IEEE 512 tahun 1992, sehingga diperlukan lebih dari satu filter untuk mengurangi harmonisa.
\end{abstract}

Kata Kunci- Kualitas Daya, PLTS, Harmonisa, Filter Pasif.

\footnotetext{
${ }^{1}$ Mahasiswa, Jurusan Teknik Elektro Fakultas Teknik Universitas Udayana, Jl. Pendidikan I perumahan. Graha Kerti blok H/6 Denpasar Selatan 80224 (tlp:083119635350; e-mail: idawegbayu@gmail.com)

2, 3 Staf pengajar,Jurusan Teknik Elektro Fakultas Teknik Universitas Udayana, Jln. Jalan Kampus Bukit Jimbaran 80361 INDONESIA (telp: 0361-703315; fax: 0361-4321; e-mail: cokindra@unud.ac.id
}

\section{PENDAHULUAN}

Setiap pembangkit listrik, memiliki beberapa permasalahan kualitas daya yang sangat mempengaruhi suatu sistem tenaga listrik, salah satu diantaranya adalah harmonisa. Harmonisa adalah gejala pembentukan gelombang-gelombang sinus dengan frekuensi kelipatan dari frekuensi fundamental. Gelombang harmonisa ini akan menumpang pada gelombang sinus murni sehingga terbentuk cacat gelombang (distorsi) yang merupakan hasil penjumlahan gelombang sinus murni dengan gelombang harmonisa. Harmonisa ini menyebabkan distorsi tegangan dan arus, di mana ia memiliki frekuensi yang merupakan kelipatan dari frekuensi dasar sistem. Sehingga gelombang tegangan dan arus yang dihasilkan tidak sinusoidal murni dan pada akhirnya dapat menyebabkan gangguan pada peralatan di sistem tenaga.[1]

Pada penelitian ini akan dilakukan analisa terhadap inverter, khususnya Grid Tie Inverter saja dan akan dilakukan perhitungan berapa besar harmonisa yang dihasilkan oleh Grid Tie Inverter, dengan menghubungkan pembangkit listrik tenaga surya (PLTS) sebagai sumber energi listrik utama. Dalam hal ini harmonisa terjadi terutama akibat adanya proses switching yang terjadi ketika inverter mengubah arus listrik DC menjadi AC disamping itu inverter juga merupakan beban non linier. Hasil yang didapat dari pengukuran akan dianalisa dan dibandingkan dengan standar IEEE 512 tahun1992 apakah sesuai standar, jika belum akan diberikan solusi seperti pemasangan filter pasif (RLC) untuk mengurangi THD peralatan tersebut. Pada penelitian ini, analisa dilakukan dengan menggunakan software MATLAB.

\section{SISTEM PLTS}

\section{A. Pembangkit Listrik Tenaga Surya}

Pembangkit Listrik Tenaga Surya, adalah pembangkit yang memanfaatkan sinar matahari sebagai sumber penghasil listrik. Alat utama untuk menangkap, perubah dan penghasil listrik adalah Photovoltaic yang disebut secara umum Modul / Panel Solar Cell. Dengan alat tersebut sinar matahari dirubah menjadi listrik melalui proses aliran-aliran elektron negatif dan positif didalam cell modul tersebut karena perbedaan elektron. Hasil dari aliran elektron-elektron akan menjadi listrik DC yang dapat langsung dimanfaatkan untuk mengisi battery / aki sesuai tegangan dan ampere yang diperlukan [2].

\section{B. Grid Tie Inverter}

Grid Tie Inverter adalah perangkat konverter DC-AC yang berfungsi merubah keluaran daya DC menjadi daya AC dan dapat bekerja terhubung dengan jala-jala PLN. Pada aplikasi pembangkit surya masukan, grid tie inverter berasal dari panel 
surya dan keluaran grid tie inverter dapat dihubungkan dengan beban PLN. Untuk memperoleh bentuk gelombang keluaran AC diperlukan pola pensaklaran yang dapat dihasilkan oleh teknik PWM (Pulse Width Modulation). Rangkaian filter bisa ditambahkan pada inverter dengan tujuan untuk memperoleh bentuk gelombang yang sinusoidal. [3].

Pada GTI (Grid Tie Inverter) memiliki komponen berupa, MOSFET, induktor, kapasitor, dan diode. Pada penelitian ini, komponen-komponen tersebut dibuatkan single line diagram pada MATLAB. Single line diagram tersebut dapat dilihat pada gambar 3.

\section{Modul Surya}

Pada penelitian ini menggunakan 1 buah modul surya dengan tipe SP-50-M36 dengan rata-rata daya maksimum sebesar 50W.Arus ketika daya maksimum (Imp) sbesar 2.85A, tegangan yang dikeluarkan ketika daya maksimum (Vmp) sebesar $17.4 \mathrm{~V}$. untuk lebih jelasnya spesifikasi modul surya dapat dilihat pada tabel 1

TABEL I

SPESIFIKASI MODUL SURYA

\begin{tabular}{|l|l|}
\hline Module Type & SP- 50-M36 \\
\hline Rated Max.Power (Pmax) & $50 \mathrm{~W}$ \\
\hline Current at Pmax (Imp) & $2.85 \mathrm{~A}$ \\
\hline Voltage at Pmax (Vpmax) & $17.4 \mathrm{~V}$ \\
\hline Short-circuit current (Isc) & $3.04 \mathrm{~A}$ \\
\hline Open circuit current (Voc) & $22.4 \mathrm{~V}$ \\
\hline Dimension (mm) & $700 \times 510 \times 30$ \\
\hline Number of Cells & 36 \\
\hline Max. System Voltages & $700 \mathrm{~V}$ \\
\hline Temperature range & $-45^{\circ} \mathrm{C}-+80^{\circ} \mathrm{C}$ \\
\hline
\end{tabular}

\section{Harmonisa}

Harmonisa adalah gelombang tegangan atau arus sinusoidal yang memiliki frekuensi yang merupakan hasil kali integer dari frekuensi di mana suplai sistem dirancang untuk bekerja pada frekuensi 50 atau $60 \mathrm{~Hz}$. Pada dasarnya, harmonisa sendiri adalah gejala pembentukan gelombang dengan frekuensi yang berbeda dan merupakan perkalian bilangan bulat dengan frekuensi dasarnya. Bilangan bulat pengali frekuensi dasar disebut angka urutan harmonisa. Harmonisa sendiri disebabkan oleh adanya beban nonliniear yang digunakan pada system tenaga listrik, contohnya seperti converte, inverter, serta berbagai peralatan yang berhubungan dengan proses pensaklaran [4].

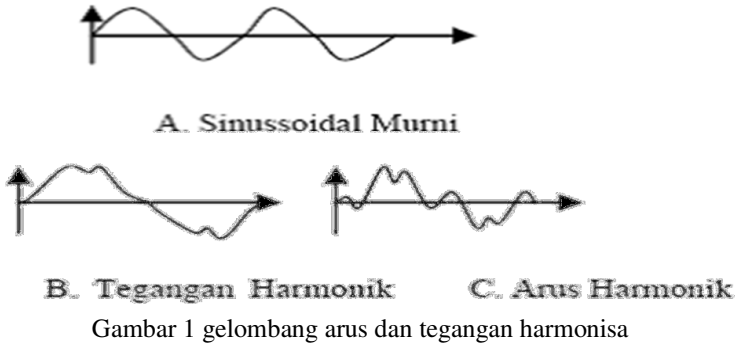

\section{E. Beban Linier}

Beban linier adalah beban yang komponen arusnya proporsional terhadap tegangannya. Terdapat hubungan yang linier antara arus dan tegangan sehingga bentuk gelombang arus akan sama dengan bentuk gelombang tegangannya, seperti terlihat pada gambar 2. Beban linier menyerap arus sinusoidal bila disuplai oleh tegangan sinusoidal [5].

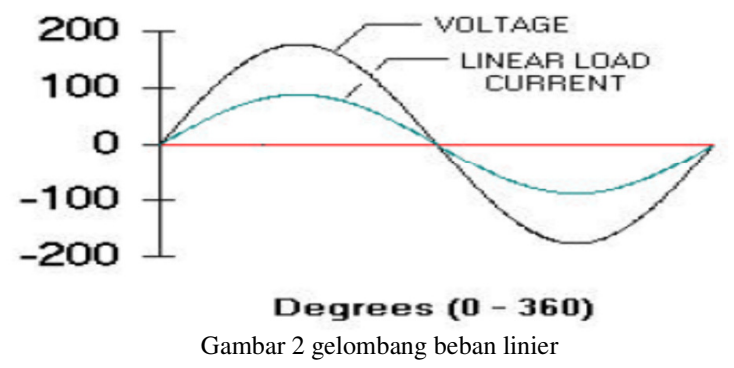

\section{F. Beban Nonlinier}

Beban yang komponen arusnya tidak proporsional terhadap komponen tegangannya, sehingga bentuk gelombang arusnya tidak sama dengan bentuk gelombang tegangannya. Tidak terdapat hubungan yang linier antara arus dan tegangan. Beban nonlinier akan menyerap arus nonsinusoidal demikian juga arus harmonik, walaupun disuplai oleh tegangan sinusoidal. Seperti gambar di bawah ini [5].

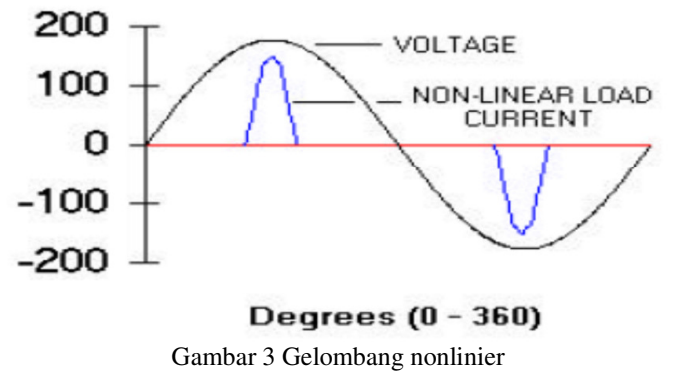

\section{G. Dampak Harmonisa}

Efek harmonisa yang terjadi dalam sistem tenaga listrik dapat mengakibatkan pengaruh yang tidak diinginkan, yaitu [3] :

p-ISSN:1693 - 2951; e-ISSN: 2503-2372 
1) Usia (life time) peralatan elektronik menjadi berkurang.

2) Interferensi sinyal (seperti Noise pada saluran telepon).

3) Rugi-rugi daya pada sistem tenaga listrik meningkat.

4) Penggunaan energi listrik menjadi tidak efisien.

5) Kualitas daya menjadi buruk, sehingga faktor daya sistem menjadi lebih rendah.

Dari dampak harmonisa tersebut maka diperlukan peredaman harmonisa untuk menghindari kerusakan peralatan tenaga listrik.

\section{H. Total Harmonic Distortions (THD)}

Distorsi harmonisa disebabkan oleh peralatan nonlinier dalam suatu sistem tenaga listrik. Sebuah peralatan dikategorikan non linier apabila peralatan tersebut mempunyai output yang nilainya tidak sebanding dengan tegangan yang diberikan [4].

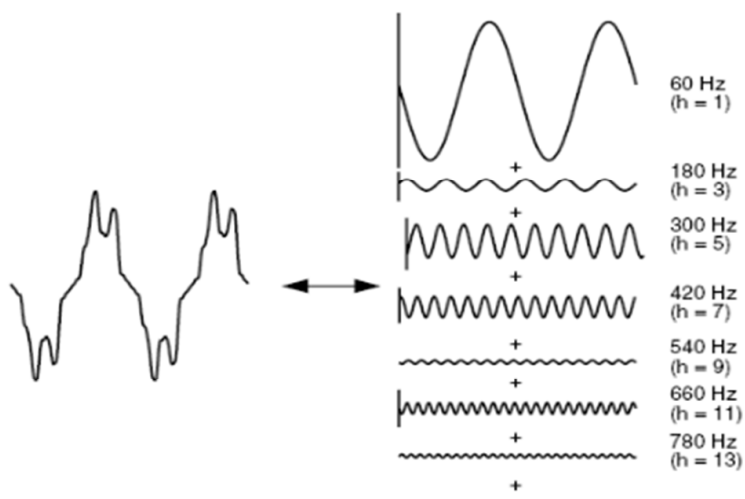

Gambar 4 gelombang terdistorsi

Pada gambar 2 memperlihatkan bentuk gelombang yang merupakan penjumlahan dari beberapa gelombang sinusoidal yang memiliki variasi frekuensi yang berbeda. Gelombang sinusoidal yang mempunyai frekuensi berbeda ini merupakan hasil kelipatan dari bilangan bulat dengan frekuensi fundamentalnya. Nilai distorsi harmonisa total (THD) dari suatu gelombang dapat dihitung menggunakan persamaan [4].

$T H D=\frac{\sqrt{\sum_{h=2}^{h \max } M_{h}^{2}}}{M 1}$

Di mana $\mathrm{M}_{h}$ adalah nilai rms komponen harmonisa $\mathrm{h}$ dari kuantitas M. kuanitas $\mathrm{M}$ dapat berupa besaran tegangan $I$ maupun besaran arus $V$, sehingga $\mathrm{THD}_{\mathrm{I}}$ nilai distorsi harmonisa arus total menjadi [4]:

$T H D_{i}=\frac{\sqrt{\sum_{h=2}^{h \max } I_{h}^{2}}}{I_{1}} \times 100 \%$
Dengan THD = Distorsi Harmonisa Total $(\%)$

$\mathrm{I}_{1}=$ Arus frekuensi dasar $(\mathrm{A})$.

$\mathrm{I}_{\mathrm{h}}=$ Arus harmonisa ke $-\mathrm{h}(\mathrm{A})$.

Sedangkan untuk nilai distorsi harmonisa tegangan total $\left(\mathrm{THD}_{\mathrm{V}}\right)[4]$ :

$T H D_{v}=\frac{\sqrt{\sum_{h=2}^{h m a x} V_{h}^{2}}}{V_{1}} \times 100 \%$

Dengan THD $=$ Distorsi Harmonisa Total $(\%)$

$\mathrm{V}_{1}=$ Tegangan frekuensi dasar $(\mathrm{A})$.

$\mathrm{V}_{\mathrm{h}}=$ Tegangan harmonisa ke $-\mathrm{h}(\mathrm{A})$.

Untuk THD memiliki standar yang sudah ditentukan dalam IEEE standart 519-1992 pada tabel 1.

TABEL II

STANDAR BATAS DISTORSI TEGANGAN HARMONIC MAKSIMUM

\begin{tabular}{|c|c|c|}
\hline Voltage at PCC & $\begin{array}{c}\text { Individual Comonent } \\
\text { Volage Distortion }\end{array}$ & $\begin{array}{c}\text { Total Voltage } \\
\text { Distortion } \\
\text { (THD }_{\mathbf{V}}\end{array}$ \\
\hline $\mathrm{V} \leq 69 \mathrm{KV}$ & $3.00 \%$ & $5.00 \%$ \\
\hline $69 \mathrm{KV}<\mathrm{V} \leq 161 \mathrm{KV}$ & $1.50 \%$ & $2.50 \%$ \\
\hline $\mathrm{V} \leq 161 \mathrm{KV}$ & $1.00 \%$ & $1.50 \%$ \\
\hline
\end{tabular}

TABEL III

STANDAR BATAS DISTORSI ARUS HARMONIC MAKSIMUM

\begin{tabular}{|c|c|}
\hline \multicolumn{2}{|c|}{$\begin{array}{c}\text { Distorsi Arus Harmonik Maksimum Dalam \% Nilai } \\
\text { Fundamental }\end{array}$} \\
\hline $\mathbf{I}_{\text {hs }} /$ IL & THD \\
\hline$<20^{*}$ & 5.0 \\
\hline $20-50$ & 8.0 \\
\hline $50-100$ & 12.0 \\
\hline $100-1000$ & 15.0 \\
\hline$>1000$ & 20.0 \\
\hline $\begin{array}{l}\text { *Seluruh perlengkapan pembangkitan daya dibatasi pada } \\
\text { nilai arus distorsi ini, tanpa melihat nilai sebenarnya dari } \\
\mathrm{I}_{\text {hs }} / \mathrm{IL}\end{array}$ \\
\hline $\mathrm{I}_{\mathrm{hs}}=$ arus hubung singkat maksimum; IL = arus beban maksimum \\
\hline
\end{tabular}

Nilai-nilai ini hanya berlaku untuk skenario kasus yang terburuk yang dapat digunakan untuk kondisi operasi dengan waktu sedikitnya satu jam. Untuk kondisi-kondisi yang sesaat seperti starting beban, switching, dan keadaan non steadystate lainnya, batas-batas ini mungkin bisa terlewati sampai $50 \%$. [6].

\section{Perancangan Filter Pasif}

Untuk merancang suatu filter, terlebih dahulu diperlukan proses identifikasi terhadap orde harmonik yang akan dilakukan eliminasi. Data harmonik tegangan terbesar digunakan untuk menentukan harmonik dari orde berapa yang akan difilter dari sistem. Kriteria yang didasarkan pada tegangan harmonik lebih tepat untuk desain filter. Hal ini disebabkan karena lebih mudah menjamin tetap berada dalam batas tegangan yang layak daripada membatasi tingkat arus akibat adanya perubahan impedansi jaringan AC. Dalam perancangan filter pasif terdapat beberapa langkah yaitu [7] : 
1) Menetukan faktor daya awal $\left(\mathrm{PF}_{0}\right)$ dan faktor daya yang diinginkan $\left(\mathrm{PF}_{1}\right)$.

2) Menentukan nilai kapasitansi kapasitor sesuai dengan kebutuhan kompensasi faktor daya yang dihitung dengan persamaan:

$\mathrm{Qc}=\mathrm{P}\left(\tan \varphi_{\text {awal }}-\tan \varphi_{\text {akhir }}\right)$

Dengan: Qc = Besarnya kompensasi daya reaktif yang diperlukan; $\mathrm{P}=$ Daya Aktif.

3) Menentukan tunning filter, untuk faktor keamanan filter dituning $5 \%$ dibawah orde aslinya.

$\mathrm{n}-(5 \% \times 3)$

Dimana: $\mathrm{n}=$ Orde harmonik

4) Menentukan nilai kapasitor dengan menggunakan persamaan:

$\mathrm{Xc}=\frac{V^{2}}{Q c}$

$\mathrm{C}=\frac{1}{2 \pi f \cdot V^{2}}$

Dimana:

$\mathrm{C}=$ Nilai kapasitor $(\mathrm{F})$

$\mathrm{V}=$ Teganga $(\mathrm{v})$

$f=$ Frekuensi $(\mathrm{Hz})$

$\mathrm{Xc}=$ Reaktansi akapsitif $(\mathrm{Ohm})$

5) Menetukan nilai induktor dengan menggunakan persamaan:

$\mathrm{X}_{\mathrm{L}}=\frac{X c}{n^{2}}$
$\mathrm{~L}=\frac{X_{c}}{(2 . \pi . f)}$

Dengan :

$\mathrm{X}_{\mathrm{L}}=$ Reaktansi induktif $(\mathrm{Ohm})$

$\mathrm{n}=$ Orde harmonik

\section{METODE PENELITIAN}

Analisis penelitian pengaruh distorsi harmonisa pada grid tie inverter dilakukan dengan cara membuat simulasi, atau simulink grid tie inverter terlebih dahulu pada software MATLAB. Alur analisis penelitian ini dapat dilihat pada gambar 3 .

\section{A. Pengumpulan Data Penelitian}

Pengumpulan data dilakukan dengan mengukur 1 buah modul surya dengan menggunakan multitester. Untuk mengukur arus listrik multitester disetting ke ampere, untuk mengukur tegangan multitester di setting ke Volt. Pengukuran dimulai dari pukul 09.00 pagi hingga pukul 15.00, dan pengambilan data diambil setiap 15 menit.

\section{B. Single Line diagram Inverter}

Pada penelitian ini menggunakan software MATLAB untuk menggambar single line diagram inverter. Single line diagram direncanakan seperti gambar 4.

\section{Menghitung Daya Semu}

Pada penelitian ini diperlukan data daya yang dihasilkan oleh modul surya untuk menghitung harmonisa yang terjadi

Bayu Satya Nugraha: Analisis Pengaruh Distorsi Harmonisa... pada inverter, dan menghitung filter yang diperlukan untuk meredam harmonisa.

\section{Analisis Tegangan Menggunakan Software MATLAB}

Analisis pada penelitian ini dibantu dengan menggunakan software MATLAB, dengan memasukan data tegangan yang didapat pada pengukuran modul surya. dan mencatat hasil yang dikeluarkan pada simulink MATLAB.

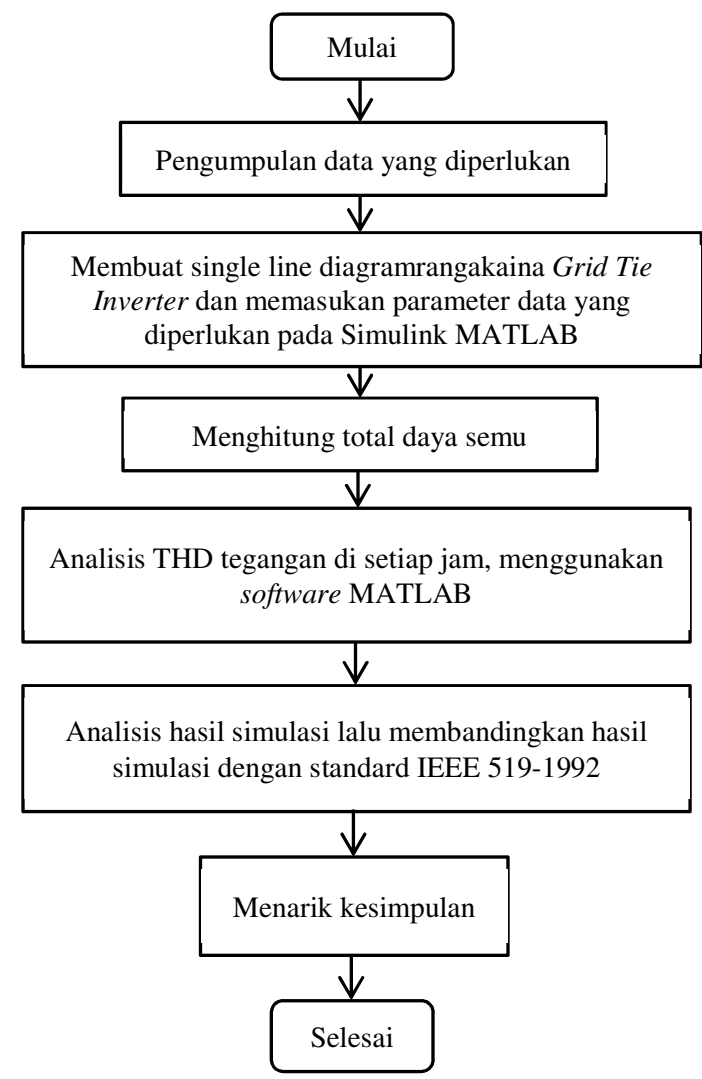

Gambar 4 Diagram Alir Penelitian 


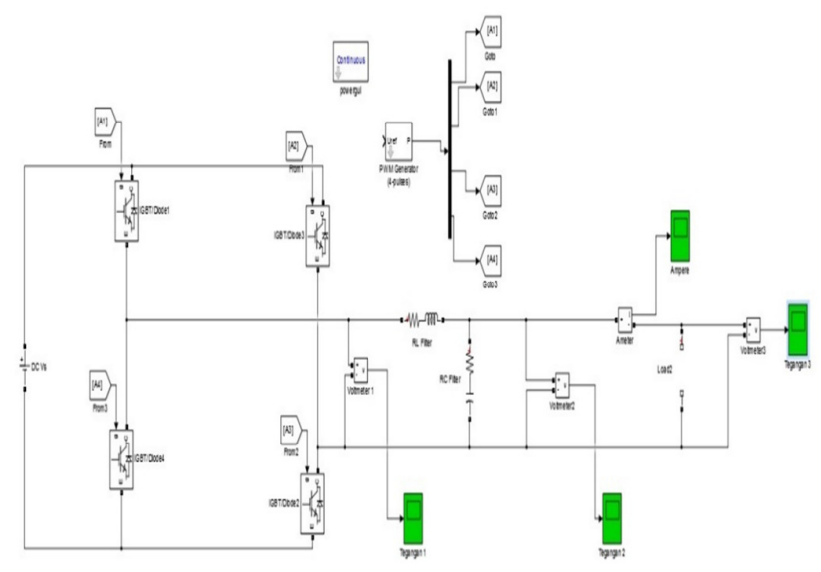

Gambar 4 Single Line Diagram

\section{E. Membandingkan Hasil Simulink Dengan Standar IEEE}

Setelah mendapatkan hasil dari simulink MATLAB, dilanjutkan dengan membandingkan standar IEEE, apakah sudah memenuhi standar atau belum memenuhi standar. Jika belum memenuhi standar maka diperlukan pemasangan filter.

\section{HASIL DAN PEMBAHASAN}

\section{A. Data Hasil Pengukuran Pada Modul Surya}

Pengambilan data tegangan dimulai pada pukul 09.00 WITA hingga pukul 15.00 WITA dengan menggunakan multitester yang di set pada volt dan ampere. Rentang waktu yang digunakan untuk mengambil data tegangan yaitu setiap 15 menit. Dari pengambilan data tersebut tegangan rata-rata yang didapat sebesar $19.58 \mathrm{~V}$ dan rata-rata arus hubung singkat yang didapat sebesar 2.61 A, perbedaan tegangan dan arus yang didapat tidak terlalu signifikan. Hasil keseluruhan dapat dapat dilihat pada tabel 3 berikut:

TABEL IV

HASIL PENGUKURAN TEGANGAN

\begin{tabular}{|c|c|c|c|c|}
\hline No. & Waktu & $\begin{array}{c}\text { Voc } \\
(\mathbf{V})\end{array}$ & Isc (A) & $\begin{array}{c}\text { Pout V x A } \\
(\text { VA) }\end{array}$ \\
\hline 1 & 09.00 & 19.9 & 2.42 & 48.16 \\
\hline 2 & 09.15 & 19.7 & 2.55 & 50.24 \\
\hline 3 & 09.30 & 19.6 & 2.56 & 50.18 \\
\hline 4 & 09.45 & 19.4 & 2.2 & 42.68 \\
\hline 5 & 10.00 & 19.6 & 2.63 & 51.55 \\
\hline 6 & 10.15 & 19.6 & 2.91 & 57.04 \\
\hline 7 & 10.30 & 19.2 & 2.6 & 49.92 \\
\hline 8 & 10.45 & 19.3 & 2.75 & 53.08 \\
\hline 9 & 11.00 & 19.2 & 2.5 & 48.00 \\
\hline 10 & 11.15 & 19.3 & 2.6 & 50.18 \\
\hline 11 & 11.30 & 19.3 & 2.5 & 48.25 \\
\hline 12 & 11.45 & 19.3 & 2.53 & 48.83 \\
\hline 13 & 12.00 & 19.2 & 2.46 & 47.23 \\
\hline 14 & 12.15 & 20.6 & 2.68 & 55.208 \\
\hline
\end{tabular}

\begin{tabular}{|c|c|c|c|c|}
\hline 15 & 12.30 & 20.7 & 2.75 & 56.925 \\
\hline 16 & 12.45 & 20 & 2.77 & 55.4 \\
\hline 17 & 13.00 & 19.7 & 2.81 & 55.357 \\
\hline 18 & 13.15 & 19.8 & 2.8 & 55.44 \\
\hline 19 & 13.30 & 19.7 & 2.71 & 53.387 \\
\hline 20 & 13.45 & 19.6 & 2.61 & 51.156 \\
\hline 21 & 14.00 & 19.2 & 2.64 & 50.688 \\
\hline 22 & 14.15 & 19.2 & 2.66 & 51.072 \\
\hline 23 & 14.30 & 19.3 & 2.47 & 47.671 \\
\hline 24 & 14.45 & 19.5 & 2.64 & 51.48 \\
\hline 25 & 15.00 & 19.5 & 2.55 & 49.725 \\
\hline
\end{tabular}

\section{B. Hasil Pengukuran THDv}

Untuk hasil pengukuran pada MATLAB hasil rata-rata THDv yang didapat dari pukul 09.00 hingga pukul 15.00 adalah sebesar $38.94 \%$, sedangkan untuk hasil tiap 15 menit didapat sebesar $38.94 \%$. Hasil yang didapat pada Simulink MATLAB tidak terdapat selisih antar THDv satu dengan yang lain, ini disebabkan karena perbedaan tegangan yang didapat tidak terlalu besar.

Salah satu contoh perhitungan Total Harmonic Distortion tegangan (THDv) yaitu pada tegangan $19.9 \mathrm{~V}$, dengan nilai $\mathrm{h}_{1}=24.53, \mathrm{~h}_{2}=4.97, \mathrm{~h}_{3}=4.97$ yaitu sebagai berikut:

$T H D v=\frac{\sqrt{4.97^{2}+6.46^{2}+4.97^{2}}}{24.53} \times 100 \%=38.91 \%$

Selisih hasil untuk tegangan 19.9V Simulink MATLAB dengan perhitungan manual adalah sebesar $0.03 \%$. Keseluruhan hasil dari perhitungan dapat dilihat pada tabel 4 berikut:

TABEL V

PERBANDINGAN HASIL THDV PADA PERHITUNGAN MANUAL DENGAN SIMULINK MATLAB

\begin{tabular}{|l|c|c|c|c|}
\hline No. & $\begin{array}{c}\text { Teganga } \\
\text { n (V) }\end{array}$ & $\begin{array}{c}\text { Hasil THD } \\
\text { pada } \\
\text { simulasi } \\
\text { MATLAB } \\
(\%)\end{array}$ & $\begin{array}{c}\text { Hasil THD } \\
\text { pada } \\
\text { perhitungan } \\
(\%)\end{array}$ & $\begin{array}{c}\text { Perbedaan } \\
\text { Hasil } \\
\text { Perhitungan } \\
\text { dengan } \\
\text { simulasi }\end{array}$ \\
\hline 1 & 19.9 & $38.94 \%$ & $38.91 \%$ & $0.03 \%$ \\
\hline 2 & 19.7 & $38.94 \%$ & $38.93 \%$ & $0.01 \%$ \\
\hline 3 & 19.6 & $38.94 \%$ & $38.93 \%$ & $0.01 \%$ \\
\hline 4 & 19.4 & $38.94 \%$ & $38.95 \%$ & $0.01 \%$ \\
\hline 5 & 19.2 & $38.94 \%$ & $38.92 \%$ & $0.02 \%$ \\
\hline 6 & 19.3 & $38.94 \%$ & $38.93 \%$ & $0.01 \%$ \\
\hline 7 & 20.6 & $38.94 \%$ & $38.93 \%$ & $0.01 \%$ \\
\hline 8 & 20.7 & $38.94 \%$ & $38.91 \%$ & $0.02 \%$ \\
\hline 9 & 20 & $38.94 \%$ & $38.93 \%$ & $0.01 \%$ \\
\hline 10 & 19.8 & $38.94 \%$ & $38.94 \%$ & $0.00 \%$ \\
\hline 11 & 19.5 & $38.94 \%$ & $38.91 \%$ & $0.03 \%$ \\
\hline
\end{tabular}

Dari hasil THD pada Simulink Matlab 38,94\% dan perhitungan yang didapat melebihi standard IEEE yaitu sebesar $\geq 5 \%$; sehingga diperlukan pemasangan filter untuk meredam harmonisa. 


\section{Perancangan Filter Pasif}

Berdasarkan data pengukuran yang dilakukan, diperoleh nilai daya aktif (P) sebesar 43.44 watt, daya kompleks (S) sebesar 51.15 VA, tegangan nominal (V) $19.58 \mathrm{~V}$, resistor 7.5 ohm. Harmonik terbesar ada pada orde ke-3 sehingga filter pasif akan didesain untuk mereduksi orde ke-3. Setelah dilakukan identifkasi terhadap orde yang akan dieliminasi, selanjutnya adalah menentukan nilai Power Factor (PF). Dalam tugas akhir ini menggunakan PF sebesar 0.85 . perancangan filternya adalah sebagai berikut:

1) Menentukan $P F$ awal dan akhir

PF awal $=0.85 \varphi=31.8^{\circ}$

$\mathrm{PF}$ akhir $=0.98 \varphi=9.94^{\circ}$

2) Menentukan daya reaktif

$\mathrm{Qc}=43.44 \times\left(\tan 31.8^{\circ}-\tan 9.94^{\circ}\right)$

$\mathrm{Qc}=43.44 \times(0.62-0.18)$

$\mathrm{Qc}=43.44 \times(0.44)$

$\mathrm{Qc}=19.11 \mathrm{VAR}$

3) Menentukan frekuensi tuning, untuk faktor keamanan filter di tuning $5 \%$ dibawah orde aslinya.

$3-(5 \% \times 3)=2.85$

4) Menentukan nilai kapasitor

$$
\begin{aligned}
& \mathrm{Xc}=\frac{19.58^{2}}{19.11}=\frac{383.38}{19.11}=20.06 \Omega \\
& \mathrm{C}=\frac{1}{2.3 .14 .50 .20 .06}=1.59 \times 10^{-4} \mathrm{~F}
\end{aligned}
$$

5) Menentukan nilai inductor

$$
\begin{aligned}
& \mathrm{X}_{\mathrm{L}}=\frac{20.06}{2.85^{2}}=\frac{20.06}{8.12}=2.47 \Omega \\
& \mathrm{L}=\frac{2.47}{2.3 .14 .50}=\frac{2.47}{314} .=7.87 \times 10^{-3} \mathrm{H}
\end{aligned}
$$

\section{Pemasangan Filter Pasif}

Setelah terpasangnya filter pada Simulink MATLAB, kemudian filter di setting sesuai dengan data yang telah di hitung sebelumnya. Untuk resistornya yang bernilai $7.5 \Omega$, dengan kapasitornya bernilai $1.59 \times 10^{-4} \mathrm{~F}$, dan untuk nilai induktornya adalah $7.87 \times 10^{-3}$.

Hasil THDv rata-rata yang diperoleh dari pemasangan 1 buah filter pada Simulink MATLAB adalah sebesar $27.43 \%$. hasil ini masih melebihi standard IEEE. Distorsi harmonisa dapat dikurangi dengan menambahkan jumlah filter, pada percobaan Simulink MATLAB untuk mengurangi distorsi harmonisa memerlukan 6 buah filter agar distorsi harmonisa yang dihasilkan dapat memenuhi standar IEEE 52-1992. Hasil percobaan untuk semua tegangan dapat dilihat pada tabel 6 berikut:

TABEL VI

HASIL PEMASANGAN 6 BUAH FILTER PADA SIMULINK MATLAB

\begin{tabular}{|c|c|c|c|c|c|c|}
\hline \multirow{2}{*}{$\begin{array}{c}\text { Volt } \\
(\mathbf{V})\end{array}$} & \multicolumn{6}{|c|}{ Hasil THDv pada pemasangan n buah filter } \\
\cline { 2 - 7 } & $\mathbf{1}$ & $\mathbf{2}$ & $\mathbf{3}$ & $\mathbf{4}$ & $\mathbf{5}$ & $\mathbf{6}$ \\
\hline 19.9 & 27.01 & 15.61 & 10.55 & 7.54 & 5.57 & 4.02 \\
\hline
\end{tabular}

Bayu Satya Nugraha: Analisis Pengaruh Distorsi Harmonisa...

\begin{tabular}{|l|c|c|c|c|c|c|}
\hline 19.7 & 26.99 & 15.59 & 10.57 & 7.61 & 5.41 & 4.06 \\
\hline 19.6 & 27.03 & 15.60 & 10.54 & 7.66 & 5.43 & 4.08 \\
\hline 19.4 & 27.01 & 15.58 & 10.54 & 7.58 & 5.48 & 4.11 \\
\hline 19.2 & 27.00 & 15.60 & 10.56 & 7.66 & 5.55 & 4.15 \\
\hline 19.3 & 27.00 & 15.60 & 10.60 & 7.62 & 5.51 & 4.14 \\
\hline 20.6 & 27.02 & 15.60 & 10.55 & 7.58 & 5.64 & 3.80 \\
\hline 20.7 & 27.02 & 15.61 & 10.58 & 7.54 & 5.62 & 3.80 \\
\hline 20.0 & 27.01 & 15.60 & 10.58 & 7.67 & 5.54 & 4.01 \\
\hline 19.8 & 26.99 & 15.58 & 10.61 & 7.58 & 5.60 & 4.05 \\
\hline 19.5 & 27.01 & 15.61 & 10.57 & 7.54 & 5.45 & 4.09 \\
\hline
\end{tabular}

Untuk hasil penurunan dari pemasangan filter dapat dilihat pada gambar 5 .

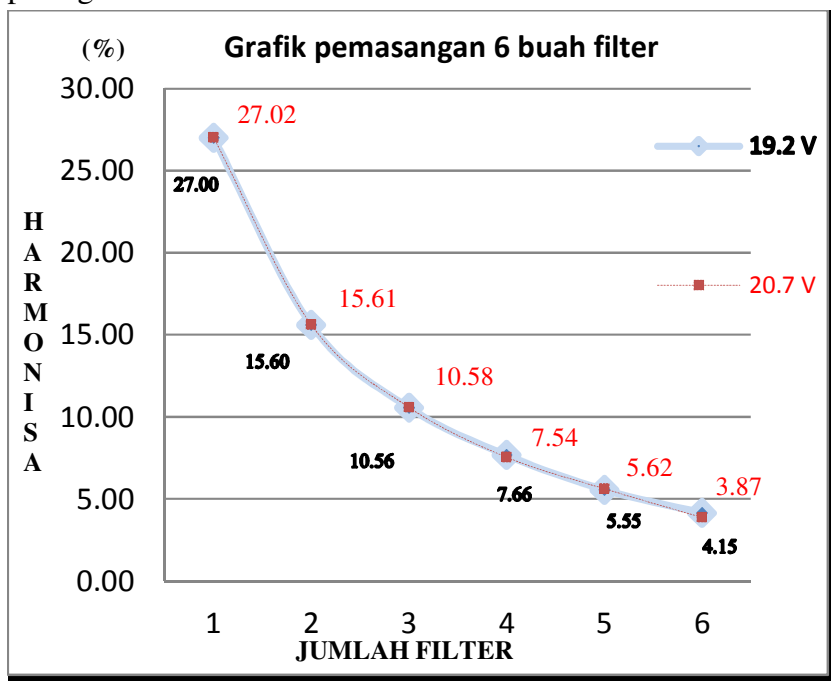

Gambar 5 Grafik hasil pemasangan 6 buah filter

Pada grafik menunjukan perbedaan antara tegangan $19.2 \mathrm{~V}$ dengan tegangan $20.7 \mathrm{~V}$, tegangan $19.2 \mathrm{~V}$ adalah tegangan terendah, yang didapat dari hasil pengukuran panel surya dan tegangan $20.7 \mathrm{~V}$ adalah tegangan tertinggi yang didapat dari hasil pengukuran panel surya. Untuk perbedaan yang terlihat pada grafik tidak terlalu signifikan dari pemasangan filter 1 hingga filter 6 , ini disebabkan karena perbedaan tegangan antara $19.2 \mathrm{~V}$ dan $20.7 \mathrm{~V}$ tidak terlalu besar. Pada simulasi penelitian ini, setelah terpasangnya filter terjadi penurunan harmonisa, hal ini disebabkan karena filter yang digunakan pada simulasi berupa Single-tuned Filter.

Filter umum ini biasa digunakan pada tegangan rendah. Rangkaian filter ini memiliki komponen berupa Resistor (R), Induktor (L), dan Kapasitor (C). Komponen-komponen tersebut dapat meredam frekuensi yang melebihi frekuensi fundamental, sehingga frekuensi yang lebih diredam dan membentuk gelombang sinusoidal.

Dari hasil pemasangan filter pada Simulink tersebut diketahui, untuk meredam harmonisa pada penelitian ini

p-ISSN:1693 - 2951; e-ISSN: 2503-2372 
diperlukan pemasangan filter sebanyak 6 buah untuk memenuhi standard IEEE std. 52-1992.

\section{KESIMPULAN}

Kesimpulan dari penelitian ini adalah sebagai berikut:

1. Hasil rata-rata THDv yang dihasilkan dari pemodelan inverter pada Simulink MATLAB sebelum terpasangnya filter untuk setiap tegangan yang berbeda, adalah sebesar $38.94 \%$. Rata-rata hasil perhitungan THDv menggunakan persamaan THDv adalah sebesar $38.93 \%$. Nilai tersebut melebihi standar IEEE 52-1992 yakni $\leq 5 \%$ untuk THDv.

2. Hasil rata-rata THDv yang dihasilkan dari pemodelan inverter pada Simulink MATLAB setelah terpasangnya filter untuk setiap tegangan yang berbeda adalah, sebesar $4.03 \%$, nilai tersebut sudah memenuhi standar IEEE untuk THDv. Jumlah filter yang diperlukan agar THDv memenuhi standar yaitu sebanyak 6 buah filter.

\section{REFERENSI}

[1] Sentosa. J. "Pengaruh Pada Gardu Trafo Tiang Daya 100 kVA di PLN APJ Surabaya Selatan" Surabaya. Universitas Kristen Petra Jurusan Teknik Elektro.2007.

[2] I K. A. Setiawan., I N. S Kumara., I W. Sukerayasa. "Analisis Unjuk Kerja Pembangkit Listrik Tenaga Surya (PLTS) Satu MWp Terinterkoneksi Jaringan Di Kayubihi Bangli". Majalah Ilmiah Teknologi Elektro. Vol. 13 No. 1.2014.

[3] Gunawan. A. " Analisa Distorsi Harmonisa Pada Penyulang Abang Karangasem Setelah Terpasangnya Pembangkit Listrik Tenaga Surya (PLTS)". Denpasar, Universitas Udayana Jurusan Teknik Elektro. 2015.

[4] A. I. Weking., I W. Rinas., A. K. Suwardana. "Simulasi Penentuan Penempatan Filter Aktif Shunt Untuk Mendapatkan Distorsi Daya Yang Terkecil Di Blue Point Bay Villa \& Spa". Majalah Ilmiah Teknologi Elektro. Vol. 12 No. 2.2013.

[5] I W. Rinas."Analisis Perbandingan Penggunaan Filter Pasif dan Filter Aktif Untuk Menanggulangi THD Pada Sistem Kelistrikan Di Ruang Puskom Jurusan Teknik Elektro Fakultas Teknik Universitas Udayana". Majalah Ilmiah Teknologi Elektro. Vol. 10 No. 1.2011.

[6] P. K. B. Sutawan., I N. S. Kumara.., W. G. Ariastina. "Simulasi Sistem Kontrol Operasi On Grid Serta Islanding Pembangkit Listrik Tenaga Surya Di Jurusan Teknik Elektro Universitas Udayana". Majalah Ilmiah Teknologi Elektro. Vol. 14 No. 2.2015.

[7] P. Hari . "Analisa Perancangan Filter Pasif Untuk Meredam Harmonik Pada Instalasi Beban Nonlinier". Techno ISSN 1410-8607, Hal. 57-67, Vol. 13 No. 1 . April 2012 